\title{
THE POLITICAL ECONOMY OF FOOD SECURITY IN INDIA: EVOLUTION AND PERFORMANCE
}

\author{
Shrutilekha Barman \\ PhD Research Scholar, Department of Political Science, \\ North-Eastern Hill University, Shillong, Meghalaya
}

\begin{abstract}
After independence, India has mostly overcome the issues of scarcity of foods and mass deaths because of starvation. Government of India established the Indian food security system under the Ministry of Consumer Affairs, Food and Public Distribution to allocate food and non-food things to India's poor at subsidized rates. The main objectives of food management system are: the distribution of foodgrains to the consumers, in particular among the vulnerable groups of the society, at affordable prices. The Government of India has enacted the National Food Security Act (NFSA) on September 12, 2013 with an aim to provide subsidized food grains to approximately two thirds of India's population.
\end{abstract}

Key words: Foodgrains, Food Security, Subsidized rates, Food Management, Consumers, National Food Security Act

Cite this Article: Shrutilekha Barman, The Political Economy of Food Security in India: Evolution and Performance, International Journal of Management, 11(12), 2020, pp 1156-1162.

http://iaeme.com/Home/issue/IJM?Volume=11\&Issue=12

\section{INTRODUCTION}

Food is the most essential human need, and it for this reason that "the human right to food is recognised in several instruments under international law (UN1999)." Food security is said to exist when all individuals, consistently, have physical, social and financial access to adequate, sheltered and nutritious food that meets their dietary needs and food inclinations for a functioning and sound life. Development of a systematic framework for managing global food security has become a need for the worldwide network. India faces the challenge and pressure to feed over 1.37 billion people. Despite economic growth and self-sufficiency in the production of food cereals, India continues to experience high levels of poverty, food insecurity and malnutrition (WFP 2015).

The National Food Security Bill (NFSB) was introduced in the Lok Sabha by the Minister of State for Consumer Affairs, Food and Public Distribution on December 22, 2011 [1]. This 
bill was expected to fill several needs to serve the needy individuals of the nation. In the first place, it would guarantee food security to the poorest section of the population and second, it would oblige the expanding food expansion. The intent of the NFSB has been outlined clearly in the report of the Lok Sabha Committee where it was stated that food security ensures both availability of foodgrains and access to sufficient amount of food at affordable price. National Food Security Act was enacted on $5^{\text {th }}$ July 2013, imparting a change of perspective in how to manage food security from the welfare-based approach to rights-based approach. NFSA incorporates the Midday Meal (MDM) Scheme, Integrated Child Development Services (ICDS) and the Public Distribution System (PDS). Further, the Act perceives maternity privileges. The MDM Scheme and the ICDS Scheme are general in nature and legitimately grants upto $75 \%$ of the rural population and $50 \%$ of the urban population to receive subsidized foodgrains under Targeted Public Distribution System. Around 80 crore people i.e. almost two thirds of the total Indian population, consequently are secured under the NFSA to receive highly subsidised foodgrains. NFSA is being implemented in all the states or union territories, on an all India premise. Identification of beneficiaries by the states or union territories is a coherent procedure that includes the exclusion of duplicate or ineligible or fake ration cards, as well as rejection due to death, relocation etc and consideration due to birth, as well as certified abandoned households. Under the provisions of this Act, Pregnant women, lactating mothers and certain categories of children are entitled to free foodgrains every day.

\section{METHODOLOGY}

The study is analytical and descriptive based on secondary sources of data. The secondary data is collected from various sources like journals, books, reports, articles and newspapers.

\section{HISTORY OF DIFFERENT FOOD SCHEMES}

Agriculture has been the foundation of the Indian economy. As per 2018, agriculture employed more than 50\% of the Indian work force and contributed 17-18\% to country's GDP [2]. Agriculture in India has been facing issues since the colonial period. The policies of the British were mainly to extract the maximum possible revenue from the farmers and gave sparse consideration in improving the agriculture productivity. The Permanent Settlement of 1793 made another class of landlords and sub-agents who were further busy in extracting maximum benefits from the tenants instead of involving themselves in agriculture. The destruction of traditional art and craft by the British constrained several craftsmen into agriculture for survival. This growing pressure on land, diminished efficiency and devastated the cultivators and prompted food deficiencies and several protests against the British. A silent catastrophe occurred in Bengal, where about 3 million Indians died in the Great Bengal Famine of 1943-1944, since all the grain produced in Bengal had been sent to British armies abroad and the war operation [3]. Little was left in India for domestic consumption and thousands died from hunger, ailment and malnutrition.

After independence, India has mostly overcome the issues of scarcity of foods and mass deaths because of starvation. Government of India established the Indian food security system under the Ministry of Consumer Affairs, Food and Public Distribution to allocate food and non-food things to India's poor at subsidized rates. The main objectives of food management system are: the distribution of foodgrains to the consumers, in particular among the vulnerable groups of the society, at affordable prices; and, to maintain the food buffers for balancing the prices and thus to provide food security [4].

The Public Distribution System (PDS) had given food security to the whole Indian population without any specific targeting of beneficiaries prior to 1997. Subsequently, it was broadly criticized as it was mainly tilted towards urban population and was unable to serve the 
whole population below the poverty line, its urban tilt and the absence of transparency and accountability. It was observed that a significant part of the PDS benefits accumulated to the non-poor and it didn't have quite a bit of an effect on the nutritional status of those in need. So, to get rid of the ambiguity of this system, government has reinstated the Targeted Public Distribution System (TPDS) mainly targeting the poor. Under the TPDS, states had to plan and update foolproof settings for identifying the poor in order to distribute the foodgrains at subsidized prices. This programme is run by the Ministry of Consumer Affairs, Govt. of India. The maximum income limit for the BPL families was kept at Rs. 15,000 per annum. Thus, the TPDS adopted by the Government of India maintains the universal character of the PDS but adds a special focus on the people below the poverty line (known as BPL).

With the purpose of making the TPDS more focused towards the very poor people, a separate category, as part of Antyodaya Anna Yojana (AAY), a Central scheme was launched in December 2000 for one crore of the poorest families. Initially, it was planned to provide 25 $\mathrm{kg}$ foodgrains per family per month, at Rs. 2 per $\mathrm{kg}$ for wheat and Rs. 3 per $\mathrm{kg}$ for rice. The quantity per family was raised to $35 \mathrm{~kg}$ a month from April 1, 2002, besides including an additional 50 lakh poorest of the poor families as beneficiaries [5]. The total coverage went up to 2.5 crore families (i.e. 38 per cent of the BPL category) by 2005-2006. The APL families were being allocated 15 to $35 \mathrm{~kg}$ per family per month depending on the availability of stocks and the past offtake. The TPDS, though an important step in ensuring food security in India, was criticised on several counts - of leakage, mis-targeting and inefficient supply chain management - in the first 10 years of its implementation. The Planning Commission estimated in March 2005 that for every Rs. 3.65 spent by the GoI, only one rupee reached BPL households [6]. Nevertheless, it was also found that the TPDS has improved over time.

Important changes came when the National Food Security Act (NFSA, also, the Right to Food Act), was passed by the Parliament of India on September 12, 2013. The Act converts into legal entitlements the schemes such as the Midday Meal Scheme(MDM), Integrated Child Development Services (ICDS) and the Public Distribution System. Coverage under NFSA includes two categories, - Antyodaya Anna Yojana (AAY) and Priority Households (PHH). The Poorest of the poor section lies under the category of AAY and are provided with $35 \mathrm{~kg}$ of foodgrains to each family every month. On the other hand, the people under $\mathrm{PHH}$ are provided with $5 \mathrm{~kg}$ per person per month.

The salient features of the NFSA are:

- Covers 75 per cent of the rural population and 50 per cent of the urban population (two-thirds of the total population).

- Persons belonging to eligible households will be able to receive $5 \mathrm{~kg}$ of foodgrains per person per month at Rs. 2 for wheat, Rs. 3 per kg for rice and Rs. 1 for coarse grains. The AAY households will continue to get $35 \mathrm{~kg}$ per household per month.

- Special focus on nutritional support to women and children, with emphasis on pregnant and lactating mothers and children up to 14 years of age. The pregnant and lactating mothers are to receive cash maternity benefits (Rs. 6000) in order to partly compensate the income losses during pregnancy and meet the additional nutritional requirements. The oldest woman in the household who is at least 18 years old should be considered as the head of the household for issuing of food ration cards.

- Grievance redressal mechanisms at the district and state levels.

Foodgrains under NFSA were to be made available at subsidized rates for an initial period of three years from the date of commencement of the Act (July 13, 2013). Thereafter, price called Central Issue Price (CIP) was to be periodically set by the central government but not 
exceeding MSP. Government has decided from time to time to continue the above-mentioned subsidized prices under NFSA and their validity has last been extended upto June, 2019 [7].

The NFSA also clearly demarcates the roles of the states or union territories and the central government. Centre is responsible for -

- Allocation of required foodgrains to states or union territories

- Transportation of foodgrains up to designated depots in each states or union territories

- Providing central assistance to states or union territories for delivery of foodgrains from designated Food Corporation of India (FCI) godowns to the doorstep of the Fair Price Shops (FPSs).

The states or union territories are responsible for -

- Effective implementation of the Act, which inter-alia includes identification of eligible households

- Issuing ration cards to eligible households

- Distribution of foodgrain entitlements to eligible households through fair price shops (FPS),

- Issuance of licenses to Fair Price Shop dealers and their monitoring

- Setting up effective grievance redressal mechanism and necessary strengthening of Targeted Public Distribution System (TPDS).

\section{OBSERVATION AND DISCUSSION}

During the year 2019-20, Government of India has allocated 603.88 lakh tonnes of foodgrains to states or union territories under NFSA and other Welfare Schemes as on 31st December 2019 as indicated in the table (Table 1). Production of foodgrains, offtake (TPDS/ NFSA + Welfare schemes), offtake as percentage of production during last five years is presented in Table 2. Table 3 shows the offtake of foodgrains during 2019-20 (upto December, 2019) under NFSA. Table 4 shows annual allocation/offtake of foodgrains under the MDM scheme from 2015-19. Annual Cash Subsidy Releases Under DBT (Rs. in Crores) is shown in Table 5. Category wise total numbers of Ration Cards in all the states and union territories till $8^{\text {th }}$ June 2020 are presented in Table 6.

Table 1 Allocation of Foodgrains to states and union territories under NFSA and Other Welfare Schemes

\begin{tabular}{clc}
\hline Sr. No. & \multicolumn{1}{c}{ Scheme } & Quantity (in lakh tonnes) \\
\hline 1 & Other Welfare Schemes & 5.11 \\
2 & Festival Natural Calamities & 2.14 \\
3 & NFSA (including ICDS \& MDM) & 596.63 \\
4 & Total & 603.88 \\
\hline
\end{tabular}

Source: Economic Survey 2019-20, Vol. II page 212[8] 
Table 2 Production of foodgrains, offtake (in million tonnes)

\begin{tabular}{cccc}
\hline Year & $\begin{array}{c}\text { Production of foodgrains minus } \\
\text { pulses }\end{array}$ & $\begin{array}{c}\text { Offtake (TPDS/ } \\
\text { NFSA + Welfare } \\
\text { schemes) }\end{array}$ & $\begin{array}{c}\text { Offtake as } \\
\text { percentage of } \\
\text { production }\end{array}$ \\
\hline $2015-16$ & 235.22 & 53.73 & 22.84 \\
$2016-17$ & 251.98 & 56.58 & 22.45 \\
$2017-18$ & 259.60 & 57.85 & 22.28 \\
$2018-19$ & 261.55 & 56.40 & 21.56 \\
2019-20 & (As per 4th Advance estimates) & 42.82 & 32.35 \\
(upto December 2019) & 132.35 & \\
\hline
\end{tabular}

Source: Economic Survey 2019-20, Vol II page 213

Table 3 Offtake of foodgrains during 2019-20 (upto December, 2019) under NFSA (in lakh million tonnes)

\begin{tabular}{lccc}
\hline \multicolumn{1}{c}{ Name of Scheme } & Rice & Wheat & Total \\
\hline TPDS & 215.74 & 164.50 & 380.24 \\
Wheat Based Nutrition & 3.93 & 5.90 & 9.83 \\
Programme & & & 15.89 \\
MDM & 12.90 & 2.99 & 20.46 \\
TPDS(Tide Over) & 15.43 & 5.03 & 426.43 \\
Total & 248 & 178.443 & \\
\hline
\end{tabular}

Source: Ministry of Consumer Affairs, Food and Public Distribution [9]

Table 4 Annual allocation and offtake of foodgrains under the MDM scheme from 2015-19 (in lakh million tonnes)

\begin{tabular}{lcccccc}
\hline & Year & \multicolumn{3}{c}{ Allocation } & \multicolumn{3}{c}{ Offtake } \\
& Wheat & Rice & Total & Wheat & Rice & Total \\
\hline $2015-16$ & 4.56 & 23.19 & 27.75 & 3.96 & 19.43 & 23.39 \\
$2016-17$ & 4.21 & 22.96 & 27.17 & 3.73 & 19.22 & 22.95 \\
$2017-18$ & 3.64 & 21.88 & 25.52 & 3.57 & 18.38 & 21.95 \\
$2018-19$ & 4.06 & 21.48 & 25.54 & 3.92 & 17.27 & 21.19 \\
$2019-20$ & 4.20 & 21.17 & 25.37 & 2.99 & 12.90 & 15.89 \\
(Upto December 2019) & & & & & &
\end{tabular}

Source: Page No. 26, ANNUAL REPORT 2019-20, Department of Food \& Public Distribution Ministry of Consumer Affairs, Food \& Public Distribution, Government of India.

Table 5 Annual Cash Subsidy Releases Under DBT ( Rs. in Crores)

\begin{tabular}{lcccc}
\hline \multicolumn{1}{c}{ UT } & $\mathbf{2 0 1 5 - 1 6}$ & $\mathbf{2 0 1 6 - 1 7}$ & $\mathbf{2 0 1 7 - 1 8}$ & $\mathbf{2 0 1 8 - 1 9}$ \\
\hline Chandigarh & 12.33 & 28.04 & 34.50 & 37.38 \\
Puducherry & 46.64 & 99.11 & 107.35 & 116.84 \\
Dadra \& Nagar Haveli & 0.35 & 5.21 & 5.01 & 5.23 \\
Total & 59.31 & 132.35 & 146.86 & 159.45 \\
\hline \multicolumn{4}{r}{ Source: Ministry of Consumer Affairs, Food \& Public Distribution [10] }
\end{tabular}

Source: Ministry of Consumer Affairs, Food \& Public Distribution [10]

Table 6 Category wise total no. of Ration Cards in all the states and union territories (As of $8^{\text {th }}$ June, 2020)

\begin{tabular}{cccccc}
\hline \multicolumn{2}{c}{ AAY } & \multicolumn{2}{c}{ PHH } & \multicolumn{2}{c}{ Total NFSA } \\
$\begin{array}{c}\text { Total No. of } \\
\text { Ration Cards }\end{array}$ & $\begin{array}{c}\text { Total No. of } \\
\text { Beneficiaries }\end{array}$ & $\begin{array}{c}\text { Total No. of } \\
\text { Ration Cards }\end{array}$ & $\begin{array}{c}\text { Total No. of } \\
\text { Beneficiaries }\end{array}$ & $\begin{array}{c}\text { Total No. of } \\
\text { Ration Cards }\end{array}$ & $\begin{array}{c}\text { Total No. of } \\
\text { Beneficiaries }\end{array}$ \\
\hline \multirow{2}{*}{23126458} & 85947506 & 203988895 & 687898141 & 227115353 & 773845647 \\
\hline
\end{tabular}

Source: Department of Food and Public Distribution, Government of India. 
Table 7 Trends in the food subsidy bill.

\begin{tabular}{cccc}
\hline Sr. No. & Year & Subsidy (Rs. Cr) & \% increase \\
\hline 1 & $2010-11$ & 62929 & 8 \\
2 & $2011-12$ & 72370 & 15 \\
3 & $2012-13$ & 84554 & 16.8 \\
4 & $2013-14$ & 89740 & 6.13 \\
5 & $2014-15$ & 113171 & 26.11 \\
6 & $2015-16$ & 134919 & 19.2 \\
7 & $2016-17$ & 130672 & -3.14 \\
8 & $2017-18$ & 139981 & 7.1 \\
9 & $2018-19$ & 171127 & 22.2 \\
10 & $2019-20$ Upto December & 150664 & - \\
\end{tabular}

Source: Annual Report of the Department of Food and Public Distribution, Ministry of Consumer Affairs, Food \& Public Distribution, GoI, 2017-18 and 2019-20.

The trends for the subsidy bill are shown in Table 7. The food subsidy bill of the Central Government has also steadily increased except for the year 2016-17, mainly due to the constant increase in the minimum support price (MSP) and the reduction in the Central Issue Price, particularly, after the implementation of the NFSA. The higher food subsidy bill causes burden on the budget and raises the fiscal deficit, exacerbating macro level inflationary pressures [11]. Therefore, Economic Survey 2019-2020 recommended that the rates of food grains under the NFSA should be reviewed to lower the food subsidy bill [12].

The Department of Food \& Public Distribution in collaboration with all states or union territories is implementing a Scheme namely Integrated Management of Public Distribution System (IM-PDS) during 2018-19 and 2019-20. The main purpose of this program is to introduce nationwide the possibility of transferring ration card holders under NFSA via 'One Nation One Ration Card' System, to raise their eligible foodgrains from any fair price store (FPS) in the country without issuing a new food ration card. Recently Union Finance Minister Nirmala Sitharaman assured 100\% coverage of national portability of one nation one ration cards by March 2021. The one nation one ration card has already covered about 83 per cent of the PDS population, benefiting about 67 crore people in 23 states. The government has also instructed all states and union territories to ensure full automation of fair price shops by March 2021 [13].

Besides the impact on economy there are certain environmental impacts of NFSA. Priyam Sengupta and Kakali Mukhopadhyay in their study have found that due to the NFSA additional greenhouse gases which is equivalent to 10.39 million metric tonnes of Carbon-dioxide would be generated [14].

\section{CONCLUSION}

From the time of independence, the food security framework has gone through different phases starting from Public Distribution System to the Targeted Public Distribution System and now to the NFSA. NFSA is an achievement throughout the entire existence of India's battle against hunger and malnutrition, as more than 80 crore people have been secured under NFSA to date to receive highly subsidized foodgrains. Despite the challenges discussed in this paper, till now this Act is yielding good results and is expected to give better result in near future by overcoming the shortcomings.

\section{RECOMMENDATION}

For an efficient food security system Government should give special attention on the availability of modern storage techniques for buffer stocks. Although this Act has been 
brought with the purpose of preventing starvation and famines through the supply of carbohydrates, it has not successfully overcome the issues of malnutrition and stunting as it doesn't include protein. Government should bring some amendments in this Act to include some protein rich food such as pulses. Besides all these education and training is necessary for the successful implementation of NFSA. Government should start some awareness programmes for the farmers to educate them about the different provisions and schemes available under Government of India.

\section{REFERENCES}

[1] https://www.prsindia.org/uploads/media/Food\%20Security/Legislative\%20Brief\%20National \%20Food\%20Security\%20Bill\%202011.pdf. Accessed on $4^{\text {th }}$ January 2020.

[2] "India economic survey 2018: Farmers gain as agriculture mechanisation speeds up, but more R\&D needed". The Financial Express. 29 January, 2018. https://www.financialexpress.com/budget/india-economic-survey-2018-for-farmersagriculture-gdp-msp/1034266/. Accessed on $5^{\text {th }}$ May, 2020.

[3] "The disaster that hit Bengal in 1940s offer a warning for the present day", Ruchir Joshi, The Hindu, April 04, 2020.

[4] Pillay D. P. K. \& Kumar T. K. M. (2018). "Food Security in India: Evolution, Efforts and Problems". Strategic Analysis. Vol. 42(6): 595-611.

[5] https://www.financialexpress.com/archive/antyodaya-scheme-many-states-yet-to-identifypoor/118030/ Accessed on $25^{\text {th }}$ May, 2020.

[6] Poor Distribution System, Indian Express, 24 May 2007, http://openlib.org/home/ila/MEDIA/2007/pds.html. Accessed on $17^{\text {th }}$ April, 2020.

[7] https://dfpd.gov.in/pds-cipunfsa.htm. Accessed on $4^{\text {th }}$ January 2020.

[8] https://www.indiabudget.gov.in/economicsurvey/doc/vol2chapter/echap07_vol2.pdf. Accessed on 17th April, 2020.

[9] https://www.annavitran.nic.in/welcome. Accessed on $4^{\text {th }}$ January, 2020.

[10] https://dfpd.gov.in/pds-dbt.htm. Accessed on $4^{\text {th }}$ January, 2020.

[11] Ashok Gulati; et al. (December 2012). "National Food Security Bill, Challenges and options, Discussion Paper No.2". Comission on Agricultural Costs and Prices, Ministry of Agriculture, Government of India.

[12] Economic Survey suggests revision of rates and coverage under NFSA, The Economic Times, Jan31, 2020.

[13] https://timesofindia.indiatimes.com/business/india-business/government-announces-onenation-one-ration-card-for-migrant-workers/articleshow/75738707.cms. Accessed on $4^{\text {th }}$ October, 2020.

[14] Priyam Sengupta1 and Kakali Mukhopadhyay ((2016). "Economic and Environmental Impact of National Food Security Act of India ", Agricultural and Food Economics. Vol. 4(5):1-23. 